\title{
A Phenomenographic Study in Understanding Architecture Students' Approaches to Learning the Coursework of Architectural Design
}

\author{
Ashok lyer \& Andrew Roberts \\ Welsh School of Architecture, Cardiff University, UK
}

Corresponding author:

Ashok lyer, Welsh School of Architecture, Cardiff University, UK

Email: iyerag@cardiff.ac.uk

\begin{abstract}
This article looks at architecture students' changes in approach to design learning between the first and fourth years of the architecture programme; charting the variation in the said approaches and exploring the reasons for the differences. The study, which aimed to use phenomenography to understand such approaches with the objective of exploring the variation from a qualitative perspective, was undertaken using a sample of 39 students in two colleges of architecture in India.
\end{abstract}

The semi-structured interviews were carried out using phenomenography and focused on the students' approaches to learning the coursework of architectural design from the first year and fourth year using an architectural design project as the learning context. The study was conducted to chart the learning approaches that emerged and relate them to deep and surface approaches to learning.

The study was carried out on the lines of earlier phenomenographic studies that aimed to understand the variation in the approaches to learning of fashion design students based in various institutions in the United Kingdom.

Keywords: phenomenography, approaches to learning, architectural design

\section{The Research Question}

How might the approaches to design learning undertaken by architecture students' change between the first and fourth years of the architecture programme? Why is there a variation in the approaches to learning and what are the reasons for any differences?

\section{Introduction}

The approaches to design learning have been explored as a personal journey through the experiences of well-known architects (Zumthor 1998) and as an important facet of reflective practice gained through professional knowledge and the academic journey in the architectural school (Schon 1996). They have also been explored through design exercises 
undertaken by the student of architecture and their reflection in architectural practice (Unwin 2012). Writers in architectural education commonly draw a distinction between the design and learning processes that students undertake and the final output of their work, or the product. The evolution of the same from a product to a process-centred approach involving the experiences of architecture students has been explored in the current study using phenomenography as the research methodology. The chosen methodology looks at the research question with specific reference to the change in the learning approaches of architecture students between their first and fourth years; which is the focus of the study.

Similar studies have been conducted in fashion design by Drew et al. (2001), comparing students' approaches to learning with Marton \& Säljö's (1976) concept of deep and surface approaches to learning.

Design education from a micro to macro perspective amalgamates fields such as product and fashion design, but also looks at the built environment within the realm of interior design, architecture and planning. Phenomenographic studies in these fields of design education would further widen the scope of this research approach, undertaken in the earlier studies on fashion design education. The research question has been explored using phenomenography as there is little published evidence of the chosen methodology being used to investigate the approaches to design learning for architecture students.

\section{Phenomenography as a research approach}

Marton (1992) defined phenomenography as "the empirical study of the limited number of qualitatively different ways in which we could experience, conceptualise, and understand various phenomena in and aspects of the world around us. These differing experiences, understanding, etc. are characterized in terms of categories of description, logically related to each other, and forming hierarchies in relation to the given criteria" (Drew et al. 2001). In simple terms "phenomenography enables the researcher to identify the range of different ways in which people understand and experience the same thing" and "is interested primarily in surfacing variation of experience and understanding"(Cousin 2009). Marton (1992) stated that "each phenomenon in our world can be seen and understood in only a limited number of distinctively different ways". He extrapolated by stating that "understanding is defined as the experiential relations between an individual and a phenomenon"(Marton 1992). Thus, a phenomenographic study helps to map the experiences based on the understandings of the participating individuals with reference to the phenomenon. Svensson (1997) stated that the theoretical foundations of phenomenography are based on its close relation to the epistemological and ontological assumptions from a methodological point of view and that it looks into the nature of knowledge and its essence of being, which is the central characteristic, through its explorative methodology of data collection, of conceptions and formulations, through thoughts and language. Phenomenography involves the identification of a limited number of "qualitative different experiences and understanding of a particular phenomenon"(Cousin 2009) and the emerging categories of description reflect the findings of the study through the outcome of the said phenomenon.

Phenomenography as a research approach "has its roots in the general scientific tradition" and "represents a reaction against, and an alternative to, the then dominant tradition of positivistic, behaviouristic and quantitative research" and its fundamental assumptions seem to point to the relational and holistic nature of knowledge; with "conceptions being the central form of knowledge"(Svensson 1997). The categories of description identified, based on the experiences of the participants, hold the key to identifying conceptions and understanding the particular phenomenon. Säljö (1997), one of the pioneers of phenomenography, has taken a critical look at interviews, the core object of this methodology where are articulated the "ways of experiencing" and the relationship 
between discourse and experience' since the phenomenographic researcher may be connecting utterances to the experience rather than to the relationship (Säljö 1997).

The possibility of connecting the original experience with the participant is ruled out as the "scientific knowledge about conceptions is based on the exploration of delimitations and holistic meanings of objects as conceptualized" and "is based on differentiation, abstraction, reduction and comparison of meaning" (Svensson 1997). Thus, phenomenography is based on disconnecting the original experiences from that of the participants, on the iteration and filtration of these experiences by differentiating and abstracting them to come up with categories of description.

\section{Phenomenographic Approaches in Higher Education}

The importance and the validity of phenomenography in higher education are based on the seminal research by Marton \& Säljö (1976) as part of the original Gothenburg research group. Their work assisted in qualitatively looking at different levels of understanding and they undertook a detailed analysis of the students' descriptions of the treatment of the task, which helped formulate the distinction between deep and surface approaches to learning (Entwistle 1997). This qualitative differentiation was the key with its specific reference to phenomenography and the ongoing research into higher education as the students' experiences in understanding the approaches to learning was the central part of this research method. Marton \& Säljö (1976) analysed the responses of several students who were asked to read an extract from a textbook. The students were instructed that questions would be based on their understanding of the text within the extract. The authors found "that while some students tried to make sense of the text, others placed emphasis on memorizing it; these seemingly opposing study strategies were described as deep and surface learning respectively"(Cousin 2009). Deep and surface approaches as metaphors had a lasting impact on the ongoing research in higher education in the three decades that followed. Cousin (2009) feels that "it is important to note that Marton and Säljö never claimed that deep and surface approaches are innate attributes of students; they accepted that the same student might use both approaches at different times, depending on the task in hand"(Cousin 2009).

Booth (1997) stated that in phenomenography, two aspects of learning as a phenomenon are questioned; these include the "What" of learning and the "How" of learning. She goes on to describe the "What" as "the conception held of the content of the learning task" and the "How" as that which "concerns more the nature of the act of tackling the learning task'; commenting further that "the teacher has to take an analytical stance to the phenomena to be taught", help the learners "reveal their experience of learning" and also "ensure that the tasks of learning are integrated into that world which the learners experience" (Booth 1997).

\section{Phenomenography and Design Education}

Phenomenography has been applied to qualitatively study the teaching and learning approaches of teachers and students in the various creative fields in design education, with the exception of architectural education. The current study into the approaches to design learning of students of architecture seeks to reflect the effectiveness of phenomenography within the realm of architectural education. The variation in design teachers' approaches to teaching design was noted by Trigwell (2002), who reported "a significant variation in descriptions of how design teaching is approached but that overall, the approaches adopted by design teachers are described as being more student-focused than most other areas of higher-education teaching". These variations were identified using the quantitative method of the Approaches to Teaching Inventory (ATI) and the author found similar variations by comparing the same with studies of qualitative descriptions of design 
teaching (Trigwell 2002). Drew et al. (2001) have explored "issues associated with phenomenographic methodology used in a study to investigate the qualitatively different ways that students approach their learning in the context of first and second year fashion design courses" (Drew et al. 2001). The methodology applied in this study clearly indicated that the process to acquiring design competence followed paths that traversed the extremes between deep and surface approaches to learning proposed by Marton \& Säljö (1976).

The categories of approaches to learning in fashion design identified by Drew et al. (2001) included product-focused strategies intended to demonstrate technical competence and to develop the design process, process-focused strategies aimed at developing the design process and a concept-focused strategy to develop the student's own concepts, while the outcome space that revolved around the "focus of the learning" was based on "the strategy and intention dimensions" of that focus (Drew et al. 2001). Drew and colleagues have elaborated upon both visual metaphor as the fundamental basis for the development of concepts and upon the prominence of the visual metaphor within the approaches to learning adopted by the student in comparison to the process- and product-oriented approach that is generally adopted (see table 1). Bailey's study (2002) on a fashion design project pointed to four approaches to learning including two that shared the features described as deep and surface approaches. She has emphasised further research in other streams of design education "to discover whether other art and design students show a similar range of variation in approach" (Bailey 2002). The four different approaches are similar to those outlined in the earlier study but reflect the incorporation of empathy and engagement in the learning approaches of the fashion design student, and thus their being in a position "to engage with the student's [i.e. their own] lived experience" (Ashworth \& Lucas 2000). Bailey (2002) has defined the outcome space as shown in table 2, which indicates that the range in design education in a practice-based learning context is deeper in comparison to the text-based learning context of deep and surface approaches.

Table 1 The strategy and intention dimensions of the categories of approaches to learning fashion courses (Drew et al. 2001).

\begin{tabular}{|c|c|c|c|}
\hline Strategy & & Intention & \\
\hline Focus of learning & $\begin{array}{l}\text { Develop technical } \\
\text { competence }\end{array}$ & $\begin{array}{l}\text { Develop design } \\
\text { process }\end{array}$ & $\begin{array}{l}\text { Develop own } \\
\text { conceptions }\end{array}$ \\
\hline $\begin{array}{l}\text { Making an artefact } \\
\text { (product focus) }\end{array}$ & Approach A & Approach B & \\
\hline $\begin{array}{l}\text { Experimenting with process } \\
\text { (process focus) }\end{array}$ & & Approach C & \\
\hline $\begin{array}{l}\text { Visualising of concepts } \\
\text { (concept focus) }\end{array}$ & & & Approach D \\
\hline
\end{tabular}

Bailey (2002) correlates and compares each dimension of the approach within the practice-based learning context and the text-based learning context as illustrated in Tables 3, 4 and 5. In Table 3, "the focus of learning" indicates that the design process as a distinctive learning approach seems to be the intermediary between "visualisation of concepts" which correlates with a deep approach and the "task of producing [the] artifact", which in turn correlates with the surface approach. Table 4, "learning intention" indicates that the students seem to be tending to develop a higher level of technical competence, 
with some developing their own design practice and, at the highest level, trying "to develop one's [i.e. their] own conceptions"(Bailey 2002). The importance of design as a learning process is brought to the fore with reference to practice-based learning and a clear bridge between the deep and surface approaches related to text-based learning. In Table 5, Bailey (2002) presents the learning activities within the practice-based learning context by emphasising the design process as a learning approach. "Experimenting with techniques and procedures" and "Rehearsing techniques and procedures" correlate with the approaches relating to deep and surface approaches, which in turn seem to be moving towards the conceptual real-world experience at one end and "memorizing techniques and procedures" (Bailey 2002) at the other end of the learning spectrum. The studies by Drew et al. (2001), Bailey (2002) point to the distinct difference in approach that needs to be adopted in the practice-based learning context, especially in the case of design education. Their work constitutes foundational research for the current study, which

Table 2 Outcome Space of approaches to learning fashion design (Bailey 2002).

\begin{tabular}{lccc}
\hline & \multicolumn{3}{c}{ Referential: intention / act of learning } \\
\cline { 2 - 4 } $\begin{array}{l}\text { Structural: } \\
\text { focus of the } \\
\text { learning }\end{array}$ & $\begin{array}{c}\text { To develop technical } \\
\text { competence through } \\
\text { memorising and reproducing }\end{array}$ & $\begin{array}{c}\text { To develop one's own } \\
\text { design practice through } \\
\text { rehearsing and } \\
\text { experimenting }\end{array}$ & $\begin{array}{c}\text { To develop one's own } \\
\text { conceptions of fashion } \\
\text { through seeking meaning }\end{array}$ \\
\hline $\begin{array}{c}\text { Production of } \\
\text { artworks or } \\
\text { artefacts }\end{array}$ & Approach A & Approach B & \\
(Product focus) & & \\
$\begin{array}{l}\text { Process of } \\
\text { designing }\end{array}$ & Approach C & \\
(Process focus) & & \\
$\begin{array}{l}\text { Visualisation } \\
\text { of concepts }\end{array}$ & & Approach D \\
(Concept focus) & & & \\
\hline
\end{tabular}

Table 3 The Focus of Learning (Bailey 2002).

\begin{tabular}{|c|c|c|c|}
\hline \multirow{3}{*}{$\begin{array}{l}\text { Text-based } \\
\text { Practice-based }\end{array}$} & \multicolumn{3}{|c|}{ 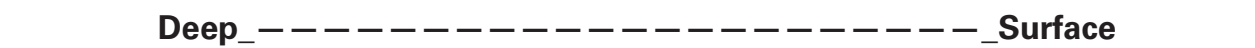 } \\
\hline & Meaning of text & & Task of reading text \\
\hline & Visualisation of concepts & Design Process & Task of producing artefact \\
\hline
\end{tabular}

Table 4 Learning intention (Bailey 2002).

\begin{tabular}{llll}
\hline & \multicolumn{2}{c}{ Deep_- ------------------ Surface } \\
\hline Text-based & To understand & To reproduce \\
Practice-based & $\begin{array}{c}\text { To develop one's own } \\
\text { conceptions }\end{array}$ & $\begin{array}{c}\text { To develop one's own } \\
\text { design practice }\end{array}$ & $\begin{array}{c}\text { To develop technical } \\
\text { competence }\end{array}$ \\
\hline
\end{tabular}


Table 5 Learning activities (Bailey 2002).

\begin{tabular}{|c|c|c|c|c|}
\hline \multirow[b]{2}{*}{ Text-based } & \multicolumn{4}{|c|}{ Deep_--ー-ー- ------------------ _Surface } \\
\hline & $\begin{array}{l}\text { Organising and } \\
\text { integrating } \\
\text { content }\end{array}$ & & & Memorizing content \\
\hline Practice-based & $\begin{array}{l}\text { Relating fashion } \\
\text { to own life } \\
\text { world }\end{array}$ & $\begin{array}{l}\text { Experimenting with } \\
\text { techniques and } \\
\text { procedures }\end{array}$ & $\begin{array}{l}\text { Rehearsing } \\
\text { techniques and } \\
\text { procedures }\end{array}$ & $\begin{array}{l}\text { Memorising } \\
\text { techniques and } \\
\text { procedures }\end{array}$ \\
\hline
\end{tabular}

examines the practice-based learning context of architecture education with specific emphasis on the coursework of architectural design.

\section{Other studies using phenomenographic approaches in design-oriented activities and situations}

A study conducted by Isomäki (2007) on "Information Systems (IS) Designers' conceptions of human users (of IS) by drawing on in-depth interviews with 20 designers" reflects their "lived experiences in the work build up; a continuum of levels of thought, from more limited conceptions to more comprehensive ones reflecting variations of the designers' situated knowledge related to human-centred design. The resulting forms of thought indicate three different but associated levels in conceptualising users; the separatist form of thought; the functional form of thought and the holistic form of thought"(Isomäki 2007). This reflects the importance of looking at the creative process within a practice-based learning context from a different perspective in comparison to the deep and surface approaches from conceptualisation to memorisation that seem to be applicable in a text-based learning context. Isomaki correlates the conception of knowledge with specific reference to the designers, whether they are catering to technology or at macro and micro level, with specific reference to the human-centered environment at large.

Zoltowski et al. (2012) have studied the incorporation of human-centered approaches into the subject area of design. Their phenomenographic study involved 33 student designers and seven categories of description were identified. The categories formed a twodimensional outcome space in which the five categories seem to be pointing towards "human-centered design approaches" and the final two categories pointing towards technology and service oriented human-centered design. "Five of the categories were nested hierarchically. From less comprehensive to more comprehensive, those categories included: Human-centered design as 'User as Information Source Input to Linear Process,' 'Keep Users' Needs in Mind,' 'Design in Context,' 'Commitment' and 'Empathic Design.' Two categories represented ways of experiencing human-centered design that were distinct: design was not human-centered, but 'Technology-Centered' and human-centered design was not design, but 'Service'" (Zoltowski et al. 2012). Zoltowski et al. (2012) provide a pointer towards the categories of description that might arise when studying the learning approaches adopted by students while undertaking the architectural design coursework since, fundamentally, they are looking at human-centric design in architecture.

Kleiman (2008) conducted a phenomenographic study into the conceptions of creativity in higher education by interviewing 12 academics from a range of disciplines. The fundamental focus of the study was the 'definition of creativity,' as manifested through a range of statements and correlative to various manifestos and related studies. "Five main categories of description describing qualitatively different ways of understanding creativity in the context of learning and teaching, were constituted, and they focused varyingly on the experience of creativity as: a constraint-focused experience; a process-focused experience; a product-focused experience; a transformation-focused experience and a 
fulfilment-focused experience" (Kleiman 2008). Kleiman stated that the study is "still emergent and requires further analysis and distillation in order to depict both the relational and hierarchical aspects of the variations". He has elaborated on the emergence of some patterns and relationships in "the five key aspects of variations that, if placed on a continuum of inclusivity, would almost certainly situate creativity as a constraint-focused experience at the 'lower' end, and creativity as a fulfilment-focused experience at the 'higher' end. It would also appear logical that creativity as a process-focused experience ought to precede creativity as a product-focused experience. However, that is problematic as it is clear from the research data that there is a conception of creativity-as-process that is not linked to product"(Kleiman 2008). This study looks at the abstract conception of creativity from a 'constraint, process, product, transformation and fulfillment focused experience', which has a direct bearing on looking at architecture and the design process, which the students chart.

Svensson \& Ingerman (2010) explored technological literacy through the use of technological objects, which literacy in today's society "is increasingly integrated with technological systems". Technological literacy has been viewed through the prism of "how concrete (objects) and abstract levels (systems) are linked"(Svensson \& Ingerman 2010). The phenomenographic study looked into "pupils' experiences of technological systems as embedded in four everyday objects". The study identified "five qualitatively different ways of understanding systems, ranging from a focus on using the particular objects, over-focusing on the function of objects, seeing objects as part of a process, and seeing objects as system components, to understanding objects as embedded in systems"(Svensson \& Ingerman 2010). The authors "suggest an educational strategy for teaching about systems in technology education" (Svensson \& Ingerman 2010). Their study highlights the need to understand the influence of learning tools, ranging from manual to computer-aided approaches, and their influence on the architecture students' learning approaches.

\section{Phenomenography - the Research Method}

Phenomenography is a research method in which the investigation is predicated on students experiencing things variously. "Phenomenography is not hypothesis driven though it always starts with the broad speculation that variation of perception is likely to exist in relation to a given phenomenon" (Cousin 2009). The nature of the questions is directed at exploration of this experience. In the current study, phenomenography has been used to explore the approaches to design learning by architecture students in their first and fourth years with the focus being on their experiences in relation to their architecture coursework; other strands of literature available that make specific reference to learning approaches in architectural education have not, therefore, been analysed.

Phenomenography involves semi-structured interviews with questions that help in mapping this experience. The sample for the interviews involves a random selection of individuals among the population ranging from "a sensible minimum" of 10 (Cousin 2009). The interviews are transcribed and the collected data are compared, grouped and analysed either manually or using software. The transcribed data are studied three to four times in detail to explore the variations and through repetitive iterations and are then sorted into groups. The experiences are decontextualised and these variations are then categorised into descriptions. The set categories of description may be hierarchical or have distinctly varied positions, something reflected in the final outcome space or findings, which act as the basis for analysing the research. 


\section{Data Collection and Analysis}

The data were generated by selecting students on a random basis from the first year and fourth year of two colleges of architecture based in India. After an initial discussion with reference to the architectural design project for the relevant years, the semi-structured interviews were carried out. The interviews endeavoured to chart the approaches to learning in the coursework of architectural design by discussing the project and trying to gain a phenomenographic output by charting a pattern from the experiences of the students and identifying the underlying conceptions in their approaches to learning. The questions were based on the structure of the questionnaire created for the study for fashion design students with a set of introductory questions followed by probing questions on interviewee's approach and conceptions (Drew et al. 2001).

\section{The introductory questions (first year / fourth year)}

- What can you tell me about the coursework of architectural design?

- Can you discuss the architectural design project in the coursework in detail?

- How did you undertake this project?

- What did you expect to learn from doing this architectural design project?

Probing on process/approach (first year / fourth year)

- Can you tell me about the design process or the steps you took from the beginning to the end of the project?

- When you were doing that, what were you thinking about?

- When you say ... what exactly do you mean?

- Can you give me an example of that in architectural terms?

\section{Probing for difference in approach (fourth year)}

- How did you go about your architectural design project in the current year in comparison to the first year?

- Was there anything you would like to add?

Probing for conceptions (first year / fourth year)

- When you use the word learning there, what exactly do you mean?

- When you say you want to get more knowledge about the coursework of architectural design, what do you mean?

- What counts as understanding?

- Is all learning the same?

The interviews were recorded and transcribed and initial filtration and categorisation were undertaken through a random selection of five interviews for each of the first and fourth year architecture student groups. This initial filtration was based on the underlying intentions reflected on the design process adopted by the architecture students in the design studio. They were as follows:

- to seek direction through the faculty in the design studio;

- to see the design studio faculty as a medium for increasing self-knowledge in learning the design process;

- to recognise the value of peer evaluation in the design studio as a medium for increasing one's learning and understanding of the design process; 
- to increase one's understanding of the design process through one's own analysis.

This initial filtration, using the underlying intentions to look into the strategies and intentions from the experiences of the architecture students, revealed some interesting directions with reference to the categories of description.

\section{Identifying the Learning Approaches}

Identifying the categories of description was based on the initial filtration, and clearly indicated that the first year architecture students were predominantly approaching the coursework of architectural design as a product-oriented strategy by trying to follow the instructions of the design faculty as definitive directions or as a learning approach.

Concentration on design as a process-oriented approach by looking at the design faculty as a medium of increasing their self-knowledge was seen at a much lower level within the first year student population. The fourth-year students were seen to be adopting a conceptual approach by concentrating on the abstract levels of design. They were seen to be developing their own concepts; but the pressures and rigours of the final portfolio submissions forced a digression towards a product-centric approach.

The interim findings guided the current study as its practice-based learning context of architectural education and the learning approaches adopted by its students were based on categories of description (learning approaches), albeit these would, of course, differ from the learning context of fashion design (see Drew et al. 2001, Bailey 2002).

\section{Final Categories of Description (Learning Approaches)}

The approaches to learning adopted by the students of architecture based on their experiences while undertaking the architectural design project were clearly reflected in the underlying conceptions as six distinct categories of learning approaches. The study uncovered a wider range compared to the four categories of learning approaches identified in the earlier studies in fashion design and this finding has been extrapolated further in the analysis section.

The introduction of the architectural design coursework in the first year of the architecture programme may be viewed as the stage when the students were seen to navigate their learning approach as a step-by-step process from the design problem to its final solution. This might be considered as a learning approach close to the surface approaches described by Marton \& Säljö (1976). The final category was seen through the experiences of the architecture students when they articulated their learning approaches with reference to architectural design at a very conceptual and abstract level and these categories seemed to fit within the parameters of deep approaches given by Marton \& Säljö (1976).

The categories of description or the approaches to learning have been briefly described as follows:

Approach A An approach focused on the series of steps taken from the introduction of the design problem to the completion of the final solution with emphasis on presenting a good output and preparing a good portfolio.

Approach B An approach focused on trying to understand or experience architecture using the experiences of the faculty as a scaffold or reflecting on their instructions to present the learning outcome.

Approach C An approach focused on evolving perceptions of architecture by adopting a series of steps within the process of design that is based on a product-focused outcome. 
Approach D An approach focused on evolving the perceptions of architecture through the process of design that is based on a process-focused outcome.

Approach E An approach focused on conceptualising the thought process and using the same in the evolution of architecture based on in-depth experiences directly correlative to the perceptual psychology within the experiences of each student.

Approach F An approach that looked into the conceptual and abstract focus towards design based on an innately creative and experiential level of understanding architecture; reflected by the student.

\section{Approach A}

This approach to learning is focused on the series of steps taken by the student of architecture from the introduction of the design problem to the completion of the final solution. Here the goal of the students is on the technical presentation and execution of a competent solution to the design problem. The learning approach adopted by the student is clearly aimed at the presentation of a good portfolio.

The extracts below from randomly selected first year students' experiences provide a clear reflection of the learning approach.

S: “No sir, I don't think so. Like in engineering we can learn and study one night and give exam but for architecture we have to study step by step. Like in every class we learn something. We can't miss any class because we have only practical works. We have to make models, we have to make sheets. We learn from those sheets. We have to go for site visits and like if we are studying about doors. We have to see how door works."

S: "In architectural terms, would be, you make a structure in such a way, whatever you are designing in such a way that it doesn't get monotonous. See, it's like you enter... you exit, but when you are exiting, you feel like this space made me, get into another world. Maybe this made me think that it's different than the others. Because, usually what you see is a block standing, levels are divided, ten bedrooms, you know, like, the entire thing is divided. It's monotonous, so, I think the word would be monotonous."

The coursework of architectural design is correlated with other coursework and ideas with the rationale that the student should, using technical means, come up with a functional and correct solution, which is clearly reflected in this learning approach.

S: "Learning in architectural design is polishing your ideas and getting more imaginative. Unless and until you can imagine a structure and sketch it out, you can't make it. So architectural design helps you in that."

S: "I feel my designs are still limited, I'm still not getting out of the box and not exploring more. Like when I think of my project, I can think of various things but when it comes to building things, I restrict myself. I don't take any challenges you know. Like in this project, most of used... like $80 \%$ of us used paper, but there were few who used other forms of materials like glass or clay or something like that. So that is what you do, you challenge yourself to do it and what I' $m$ doing is I'm still restricting myself. I would want to be more challenging in my designs and something which I think, I want to show it in my work rather than thinking no... no... I don't have time and also I want to speed up my work."

This learning approach was being taken by the fourth year students who seemed to be pressed for time and wanted to complete their design portfolio and technically reflect an acceptable solution. 
S: "No, it's not the same. For say example if for me to learn any of my technical subjects and for me to learn design is completely different. So technical subjects... I feel drafting is... for me it works, because when I draft, I'm drawing and I learn so, if you ask me, I think that's great. But design can, I don't know, I think the approach towards design has to be different. So visualisation, measurement, understanding scale etc. has to really weigh, you really have to be good in that. So learning is very different for different subjects. And I think it should be addressed in different ways. A generalised attempt towards it is not really effective."

S: "a... understanding of the process will help us come up with better solutions and faster solutions. In the best way possible..."

S: "So, they have a co-relation, but a lot of people, at least in my batch. They design, the standard says 4 metres setback, I follow 4 metre setback. Some people are very standardised."

\section{Approach B}

The learning approach adopted by the students is to focus on understanding or trying to experience architecture as a design-oriented process through the instructions provided by the faculty in the design studio. Approach B is a step ahead of Approach A as the student is trying to evolve a learning approach that seems to move away from looking at just the functional and the visual aspects of the architectural design solution.

The extracts below, taken from interviews with first year students, highlight the pedestal on which the faculty of the design studio have been placed and the importance given to their instructions within the coursework.

S: "First is the site analysis where you go and analyse the site, check the directions and approach routes and things like that. You take down the measurements and also we take care of any vegetation on that site, we are not supposed to cut down any tree. So then after that we go for many case studies of existing houses, rooms etc. how they can be improved and how they can be put into our design. After case study, we start with our drafting work which includes all views, elevations, plans, sections. Then we come to our own concept. Again we start by zoning our area, listing out all the activities, also taking care of the number of members that are going to use that space. Then we make a bubble diagram and decide what space has to be used for what purposes and construction material, we take care of that. Then we are asked to come up with many concepts. We have a panel of four teachers, they analyse our concept and tell us what to add or remove. Then with our final concepts we start drafting again and then draw all sections, views, etc. and in the end, we aa... make a model which is actually the best part of the project because then you can visually see how your project has come."

S: "I wouldn't say that I'm $100 \%$ sure about my work. Every time I design something, I know it's not $100 \%$ right. There are flaws, there are good points too. And coming to faculty and discussing. They do tell you what you could do in order to make it better, so it's never like you are $100 \%$ right, you are always learning. Understanding is aa... basically how you think, how you perceive and how you make the other person believe in the idea. So you have to even convey your idea to the person."

Many fourth-year students went on to adopt this learning approach at certain intervals during their architectural design coursework with the intention of meeting the learning outcome stipulated by the institution in terms of examinations and the pressure point of final submission of the design portfolio.

S: "But that kind of enthusiasm that I used to have to design in general, has really been reduced to a chore, you know, like just finishing it off and you know just coming up with 
something that the teacher likes and that everyone is happy 'ok my jury will go well' etc. So that passion is there but not as much as I started off with..."

S: "I don't know. I mean. .. we know how to. ...I mean, we do know what the process is .. yaa... sometimes we do get confused, so we keep looking at our professors, then they will tell us something, we go do something. Might not be right, might not be what they are looking for, but, we still have to, every... all our professors also have different opinions of how to go about things. So then, if you listen to one of them, then the other will tell you that that's not right, that's not the way to do it. You know, there is conflicting opinions within the teachers as well. That's sometimes; it gets a little confusing, right. So you need to take the best of everything like, put it together."

\section{Approach C}

This learning approach, in comparison to Approach B, clearly shows that the student's focus is the evolution of one's own perceptions of architecture. The intention of the student is based on a product-focused outcome arrived at by adopting a series of steps within the process of design. These steps differ markedly from those of Approach A as they are intentionally taken by the student as a part of the experimentation process of experiencing architecture.

This innate quality seems to be adopted by a few students in the first year and they reflect the same in their experiences, reiterating the change that needs to be achieved by the student in the very process of understanding design.

S: "Yea... in a way it's same and it's different also. Like in architecture, every subject is taken into consideration like psychology of a person, history of that place and structural elements, aesthetic elements. So yea learning is a bit different I would say. It's a bit open-minded. You can put every thought into it. It has to be technical also but it should be open-minded also."

S: "Getting more knowledge in terms of architectural design is for the betterment of us. So that we can put our creativity and our knowledge both together, compiling it and we can make a very good design because there is a no limit to creativity but when it comes to reality, there is a limit and when this knowledge comes into the reality and combines with creativity, we can have better designs in future."

S: "So, the human comfort is also important. It's not just going abstract and designing whatever you want... you have to think about the person staying there... so I designed according to human comfort as well keeping in mind something about the animal and also whatever I try to design. . I I try to keep a part of nature in it. . like involve nature in it. Like that side had river and trees so I tried to bring in the river and create a peaceful environment inside. . I created a small waterfall, a small swimming pool and planted trees around the house. So that you connect with nature... like the person. When you stay in a house and if the living space has a connection with nature... so that feeling when you go out will also be carried out. So I think that is very important."

There seems to be a large number of fourth year students who have embraced this learning approach. The question as to why this seems to be the case requires further analysis, but Approach $\mathrm{C}$ seems to optimally resolve and balance two important aspects within the architectural design coursework. The students are able to dabble in the perceptual qualities of architecture, even if at a very superficial level, and balance the criteria set by the studio faculty and the institution with reference to the final submission.

S: "But. . it means a lot. I've... One aspect of it is design; the other aspect of it would... design of spaces, physical spaces. The other aspect would also be to do with philosophy, what is my philosophy, what am I communicating to people." 
S: "Understanding the human temperament and how we can optimise the space was our priority. It starts with analysis of site then we go to the case studies, by laws and references, area distribution, conceptual layout and proper area demarcation for villas, buildings etc... by calculating the footprint area, total area, floor area ratio, etc. and that's how we went about doing this project. The road network connectivity was designed, plot areas were marked. There were setbacks and gradually the design evolved and we came to the end result. It starts with the basic concept. Every architect has a concept and he wants to shape it the way he dreams about it but then you have restrictions but we try and use optimistic use of area. Optimistic use means maximum utility in the minimum area."

\section{Approach D}

The students following this learning approach are focused on sensitising themselves to the various aspects of architecture with an underlying intention to evolve their perceptions of architecture that would lead them towards Approach E. This learning approach seems to be consciously applied to the very process of design and the student appears to be working towards a process-focused outcome.

Very few first year students seem to adopt this approach as their limited exposure to architecture is seen as a barrier to added sensitivity in this context.

S: “Well. Learning. It's ... we acquire knowledge about architecture. We are new to architecture. It will be, just now. First year... so we are just learning about, just say, all the points above that I just stated like, what is comfort, what is comfort level and all that. It's all, you learn it only through literature study or, or by looking at different buildings, for example, this room where we are sitting right now. It's a classroom but it should feel like a classroom. For that everything comes into play."

S: "I think architectural design cannot be taught like a theory subject, it's what, by, when they give us more and more work, we realise, you know, we grow and realise that the changes that could be made and small things that come into our mind which we, you know, keep in mind the next time we are given another project. So, I think that's what learning is. Self-learning, more than being taught."

S: "Experiencing space basically is like. . . see ... . if you['re] just going to see . . If you just take a narrow space. Anywhere, I don't think the person would enjoy the time that he gets frustrated, maybe gets annoyed of[sic] it. You make the space in such a way that your entire site is being used and at the same time, it gives the person, that entire energy of moving around and makes him think of more, like what is going to be ahead. You feel like roaming there, you feeling like experiencing things. You have a question in mind; let's see what going to happen, ahead. Maybe there is something interesting. So, that is what the whole thing is about for me. Experiencing the space."

The fourth year students seem gradually to be moving from Approach $C$ to $D$ as their exposure towards architecture includes working in the industry and the scale of the projects they are handling is at an urban level. Thus, their learning approaches appear to be focused on the sensitivities of various aspects of architecture, which is clearly seen as the underlying intention in Approach D.

S: "What did I expect to learn... See, I expected a lot of things, like... when we started off with the whole thing... Like we had really high hopes... Because especially because of last year when... things were rushed at a very fast pace because of third year being a university year... So we know, this year sit down and learn something. I had actually expected to learn... One was go through the process of... Trial and error... Trying to build something and, you know... trying to understand why it works or why it doesn't work or why it fails and working from that... But that's what I expected, and not that it happened." 
S: "Everything that you learn registers in a different way, the books that we read. It doesn't come to us when we want. . Maybe unconsciously we are using it. . somewhere else... because we have read it somewhere... So, for me that's the difference... different kinds of learning... some things come to us then and there but some things just come to us, involuntarily... you don't remember where you have read it."

\section{Approach E}

The students using this learning approach are subconsciously focusing their minds on conceptualising the thought process and using it in the evolution of architecture. The difference from Approach $D$ is based on their innate and in-depth experience of architecture, which is seen as the underlying intention directly correlative to the perceptual psychology within the experiences of each student.

The first year students who manifested these underlying intentions were not even cognisant of the fact that they were actually on the road towards using such an innate learning approach.

S: "Say there is something I'm able to perceive in my project during the learning process; I should be able to use that in any other design I do in future. So I guess that is what understanding is."

Very few fourth year students were seen to be following this learning approach and the urban scale of the architectural design project coupled with the submission deadlines within the context of the institutions played an important role. The aspirations and the expectations of learning outcomes in specific directions with reference to the studio faculty also seemed to be an inhibitor in Approach $E$ and $F$ being the learning approach for many students, who tended to move back towards Approaches $C$ and D.

S: "And in terms of a study, it is, firstly, research; as I said, absorption. Then you get the outputs out keeping your context in mind. For me personally, my context is very important, so I need to understand my context and then, respond to it accordingly. Then, for me design will not be over till I understand the methods of construction to it. How I am going to do it, how I am going to execute it and till a point, if I cannot. For me a design will be, till a point of execution. A point I can execute. I personally feel, that no one can teach you architectural design."

S: “Nowadays, learning has come up to... just living... we went for a play and we've just noticed some detail here and there and, nowadays I am starting to find that I am learning, you know more...in an open... It's not learning in a classroom, in a studio, just end up learning wherever you are going, so I think that's how it has changed."

\section{Approach F}

There were glimpses that students were actually thinking of following this learning approach, which looked into the conceptual and the abstract focus towards design. The intentions based on the individual's innately creative and experiential level of understanding architecture were reflected by the first and fourth year students on very rare occasions while extrapolating their lived experiences about architecture.

S: "Like, you cannot hide yourself in your designs. Like what you are and how you perceive things and how you think about people and how sensitive you are reflects in every way, in your designs, even in the smallest room that you will create. That is firstly my idea. Secondly, it is that you understand these different typologies, you expose yourself to different people, different ways in which situations come about and how you work about certain areas. You gather information, you absorb it, and you make it a part of yourself, so much so that start, once you start sketching, it starts coming out in a very intuitive way, so for me, firstly... it's a lot of... for me, research is for what I am doing and whom I am doing 
it, absorbing it, and to understand, what am I, what are the best solutions that I can provide in terms of a design problem. And then it automatically flows out with, of course, a sense of my own character. That is what I understand by architectural design for now..."

S: "To me... architectural design is something... oh... on the lines of daily life. It started off in the first year as a very... you know. . .very particular subject, you had to do... And you go to college... And now... as time has progressed... It's sort of become... like... a daily thing... That... wherever you look, you are learning something... Wherever... like even as you walk down the streets, you're looking at stuff and... So, this could have been... in that way and we do that and... before you realise... and you actually realise... It's sort of taken over everything and sort of... you are doing... So that's what architectural design is. What counts as understanding... I would say... understanding counts as... basically an acceptance... When you talked about knowledge... it's when we talked about awareness and when we are gaining, we are learning, we are aware... mind is open to different things... that's just knowledge... It just about how you choose... to deal with it, your understanding of it. Your acceptance of it."

\section{Analysis \& Discussion on the Study}

The study has reflected that the learning approaches adopted by first and fourth year architecture programme students exhibit a clear variation between product-focused and process-focused approaches, moving towards concept-focused approaches. Here, the conceptual and abstract facets of the design process are reflected in an outcome space depicted as a matrix (Figure 1): the outcome space or the findings based on the structural and referential dimensions with the former focused on the approaches to learning; the latter based on the intention towards the act of the learning, as shown in Table 6. The range of qualitative differences in the approaches to learning adopted by the architecture students is reflected in the findings, which unequivocally illustrate the practice-based learning context of the architecture programme and the depth of understanding required to perceive the architectural sensibilities of the students pursuing this noble field. The findings reflect the very nature of the architecture programme and the categories of learning approaches show the greater range that is available in comparison to the deep and surface approaches within the text-based learning context. The findings reflect that the range of categories with reference to learning approaches is greater in the architecture programme at the micro to macro levels; by comparison, the architecture programme encompasses a far broader range than the fashion design programme, based on the earlier studies (Drew et al. 2001, Bailey 2002).

Detailed examination of the relational order of the categories shows that Approaches $A$ and $B$ have a product focus with the students attempting to learning architecture by following a certain set of steps and trying to execute the same as a solution-centred learning outcome. Approach $C$ seems to differ from Approaches $A$ and $B$ in that the experiential nature of understanding architecture slowly seems to be gaining ground with the students, but they appear to have a product-focus. Approaches D and E appear to raise the students' understanding of architecture to a different level as they are trying to connect their experiences of architecture to a perceptual level. The learning outcomes thus slowly evolve into to a process-focused outcome and progression towards a conceptual level. Approach $\mathrm{F}$ truly brings out the innate characteristic of the architectural sensibilities that can be equated to the deep approach, as here; we are indeed looking at reflection from students that takes us towards an understanding of the very ethos of architecture as an outcome.

With reference to the approaches to learning and how students of architecture approached the coursework of architectural design in the fourth year in comparison to the first year. The phenomenographic study clearly reflects the experiences of the students' approaches 


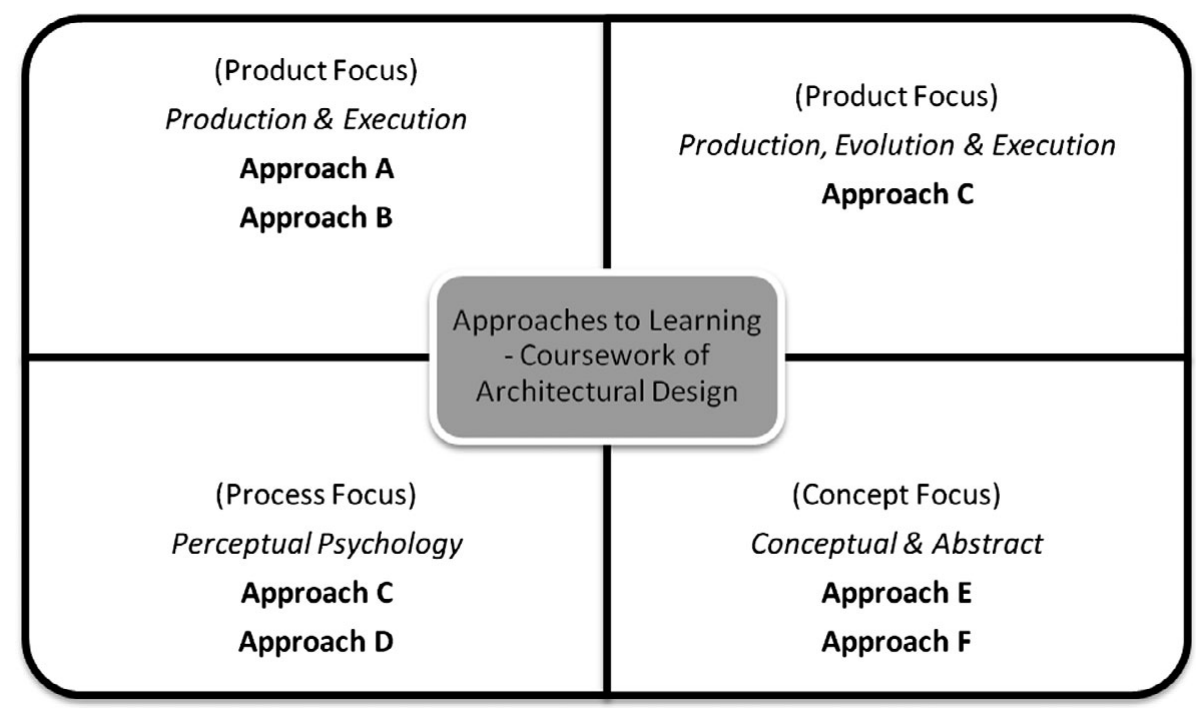

Figure 1 Matrix depicting the categories of description with reference to the approaches to learning adapted within the outcome space using the phenomenographic approach.

Table 6 Outcome Space of approaches to learning the coursework of architectural design.

\begin{tabular}{|c|c|c|c|c|}
\hline \multirow[b]{2}{*}{$\begin{array}{l}\text { Structural dimension } \\
\text { (focus) } \\
\text { Approaches to } \\
\text { learning }\end{array}$} & \multicolumn{4}{|c|}{ Referential dimension (intention): Act of learning } \\
\hline & $\begin{array}{l}\text { To develop the } \\
\text { series of steps } \\
\text { from introduction } \\
\text { to completion of } \\
\text { design project }\end{array}$ & $\begin{array}{l}\text { To develop an } \\
\text { understanding } \\
\text { based on an } \\
\text { instruction- } \\
\text { based scaffold }\end{array}$ & $\begin{array}{l}\text { To develop an } \\
\text { evolution in } \\
\text { understanding } \\
\text { based on } \\
\text { perceptual } \\
\text { psychology }\end{array}$ & $\begin{array}{l}\text { To develop one's own } \\
\text { conceptions of } \\
\text { architecture based } \\
\text { on a creative and } \\
\text { experiential level } \\
\text { of understanding }\end{array}$ \\
\hline $\begin{array}{l}\text { Production and } \\
\text { execution of } \\
\text { design project } \\
\text { (product focus) }\end{array}$ & Approach A & Approach B & & \\
\hline $\begin{array}{l}\text { Production, evolution } \\
\text { and execution of } \\
\text { design project } \\
\text { (product focus) }\end{array}$ & & & Approach C & \\
\hline $\begin{array}{l}\text { Process of design } \\
\text { based on } \\
\text { perceptual } \\
\text { psychology } \\
\text { (process focus) }\end{array}$ & & & Approach D & Approach E \\
\hline $\begin{array}{l}\text { Visualisation of } \\
\text { conceptual and } \\
\text { abstract focus } \\
\text { (concept focus) }\end{array}$ & & & & Approach F \\
\hline
\end{tabular}

to learning. It was found that the first year students were predominantly approaching the coursework of architectural design as a product -focused strategy. Approaches A, B and C were preferred, which reflected the fact that the first year students were still new to the architecture programme and the field. Their intentions to follow a product-centred approach by trying to follow the instructions of the design faculty might be viewed as a scaffold for 
absorbing as much as possible and quickly moving up the practice-based learning context ladder. There were rare moments when the first year students seemed to be following Approaches D and E, which reflected their move towards a process-focused strategy and their sensitivity towards understanding architecture at a deeper level (see Table 7).

Table 7 Outcome Space of first year students' approaches to learning the coursework of architectural design

\begin{tabular}{|c|c|c|c|c|}
\hline \multirow[b]{2}{*}{$\begin{array}{l}\text { Structural } \\
\text { dimension } \\
\text { (focus) } \\
\text { Approaches } \\
\text { to learning }\end{array}$} & \multicolumn{4}{|c|}{ Referential dimension (intention): Act of learning } \\
\hline & $\begin{array}{l}\text { To develop the } \\
\text { series of steps } \\
\text { from introduction } \\
\text { to completion of } \\
\text { design project }\end{array}$ & $\begin{array}{l}\text { To develop an } \\
\text { understanding } \\
\text { based on an } \\
\text { instruction- } \\
\text { based scaffold }\end{array}$ & $\begin{array}{c}\text { To develop an } \\
\text { evolution in } \\
\text { understanding } \\
\text { based on perceptual } \\
\text { psychology }\end{array}$ & $\begin{array}{c}\text { To develop one's } \\
\text { own conceptions } \\
\text { of architecture } \\
\text { based on creative } \\
\text { and experiential level } \\
\text { of understanding }\end{array}$ \\
\hline $\begin{array}{l}\text { Production and } \\
\text { execution of } \\
\text { design project } \\
\text { (product focus) }\end{array}$ & Approach A & Approach B & & \\
\hline $\begin{array}{l}\text { Production, evolution } \\
\text { and execution of } \\
\text { design project } \\
\text { (product focus) }\end{array}$ & & & Approa & \\
\hline $\begin{array}{l}\text { Process of design } \\
\text { based on perceptual } \\
\text { psychology } \\
\text { (process focus) }\end{array}$ & & & Approach D & Approach E \\
\hline $\begin{array}{l}\text { Visualisation of } \\
\text { conceptual and } \\
\text { abstract focus } \\
\text { (concept focus) }\end{array}$ & & & & Approach F \\
\hline
\end{tabular}

In the fourth year, students predominantly adopted Approaches $C$ and $D$ with some moving towards Approach $\mathrm{E}$; in rare instances students were seen to be using Approach $\mathrm{F}$. This reflected that, although the fourth year students were observed to be developing their own conceptions based on their perceptions and experiences of architecture, the pressures and rigours of final portfolio submissions were seen as academic hurdles taking them towards the product-centred surface approaches from the process and concept-centred deep approaches (see Table 8).

Tables 9 to 11 correlate and compare each dimension of the approaches to learning within the practice-based learning context of architectural design and fashion design but also the text-based learning context explored by Marton \& Säljö (1976). Table 9, 'The Focus on Approach to Learning', reflects the depth of the approaches to learning within the design process in the coursework of architectural design and compares the same with fashion design within the overall framework of deep and surface approaches of the text-based learning context. Table 10, 'The Act of Learning Intention', points towards the depth of architectural education within the practice-based learning context and where the macro to the micro level far exceeds the boundary of the context covered in fashion design education. This is reflected in Table 11, 'Approaches to Learning Activities', and draws on the categories of approaches derived from the current study, comparing it with the earlier 
Table 8 Outcome Space of fourth year students' approaches to learning the coursework of architectural design.

\begin{tabular}{|c|c|c|c|c|}
\hline \multirow[b]{2}{*}{$\begin{array}{l}\text { Structural } \\
\text { dimension } \\
\text { (focus) } \\
\text { Approaches to } \\
\text { learning }\end{array}$} & \multicolumn{4}{|c|}{ Referential dimension (intention): Act of learning } \\
\hline & $\begin{array}{l}\text { To develop the } \\
\text { series of steps } \\
\text { from introduction } \\
\text { to completion of } \\
\text { design project }\end{array}$ & $\begin{array}{l}\text { To develop an } \\
\text { understanding } \\
\text { based on an } \\
\text { instruction- based } \\
\text { scaffold }\end{array}$ & $\begin{array}{l}\text { To develop an } \\
\text { evolution in } \\
\text { understanding } \\
\text { based on } \\
\text { perceptual } \\
\text { psychology }\end{array}$ & $\begin{array}{c}\text { To develop } \\
\text { one's own } \\
\text { conceptions of } \\
\text { architecture } \\
\text { based on a } \\
\text { creative and } \\
\text { experiential level } \\
\text { of understanding }\end{array}$ \\
\hline $\begin{array}{l}\text { Production and } \\
\text { execution of } \\
\text { design project } \\
\text { (product focus) }\end{array}$ & Approach A & Approach B & & \\
\hline $\begin{array}{l}\text { Production, evolution } \\
\text { and execution } \\
\text { of design project } \\
\text { (product focus) }\end{array}$ & & & $\overbrace{}^{\text {Approach C }}$ & \\
\hline $\begin{array}{l}\text { Process of design } \\
\text { based on perceptual } \\
\text { psychology } \\
\text { (process focus) }\end{array}$ & & & Approach D & Approach E \\
\hline $\begin{array}{l}\text { Visualisation of } \\
\text { conceptual and } \\
\text { abstract focus } \\
\text { (concept focus) }\end{array}$ & & & & Approach F \\
\hline
\end{tabular}

Table 9 The Focus on Approach to Learning (based on Bailey 2002.

\begin{tabular}{|c|c|c|c|c|c|}
\hline \multirow[b]{2}{*}{ Text-based } & \multicolumn{5}{|c|}{ Deep_- --------------- _Surface } \\
\hline & Meaning of Text & & & Task of rea & ding text \\
\hline $\begin{array}{l}\text { Practice-based } \\
\text { (Fashion Design) }\end{array}$ & Visualisation of & concepts & process & Task of pr & ducing artefact \\
\hline $\begin{array}{l}\text { Practice-based } \\
\text { (Architectural Design) }\end{array}$ & $\begin{array}{l}\text { Visualisation } \\
\text { of conceptual } \\
\text { and abstract } \\
\text { focus }\end{array}$ & $\begin{array}{l}\text { Process of design } \\
\text { based on perceptual } \\
\text { psychology }\end{array}$ & $\begin{array}{l}\text { Productio } \\
\text { and exe } \\
\text { design }\end{array}$ & $\begin{array}{l}\text { evolution } \\
\text { ution of } \\
\text { roject }\end{array}$ & $\begin{array}{l}\text { production and } \\
\text { execution of } \\
\text { design project }\end{array}$ \\
\hline
\end{tabular}

studies by Drew et al. (2001), Bailey (2002). Tables 9 to 11 add a new dimension to the practice-based learning context with specific reference to architecture education and the further research that needs to be done within this context using phenomenography.

\section{Architectural education - the learning approaches within the practice-based learning context}

Broadbent (1973) has reflected on the notion of self-expression of the architect, which according to him is a thing of the past. He described the crisis within the profession in the mid-1960s. His viewpoint for understanding architecture through perceptual psychology is based on the way people perceive or experience a building. He has also extrapolated on its 
Table 10 The Act of Learning Intention (based on Bailey 2002).

\begin{tabular}{|c|c|c|c|c|}
\hline \multirow[b]{2}{*}{ Text-based } & \multicolumn{4}{|c|}{ 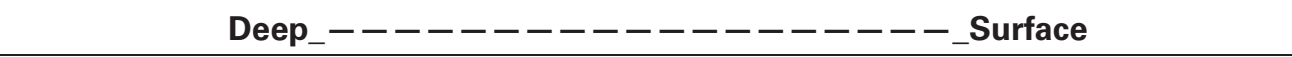 } \\
\hline & To understand & & & To reproduce \\
\hline $\begin{array}{l}\text { Practice-based } \\
\text { (Fashion Design) }\end{array}$ & $\begin{array}{l}\text { To develop one's own } \\
\text { conceptions }\end{array}$ & $\begin{array}{l}\text { To develo } \\
\text { design }\end{array}$ & $\begin{array}{l}\text { p one's own } \\
\text { practice }\end{array}$ & $\begin{array}{l}\text { To develop technical } \\
\text { competence }\end{array}$ \\
\hline $\begin{array}{l}\text { Practice-based } \\
\text { (Architectural } \\
\text { Design) }\end{array}$ & $\begin{array}{l}\text { To develop one's } \\
\text { own conceptions of } \\
\text { architecture based } \\
\text { on a creative and } \\
\text { experiential level of } \\
\text { understanding }\end{array}$ & $\begin{array}{l}\text { To develop an } \\
\text { evolution in } \\
\text { understanding } \\
\text { based on } \\
\text { perceptual } \\
\text { psychology }\end{array}$ & $\begin{array}{l}\text { To develop an } \\
\text { understanding } \\
\text { based on an } \\
\text { instruction- } \\
\text { based scaffold }\end{array}$ & $\begin{array}{l}\text { To develop the } \\
\text { series of steps } \\
\text { from introduction } \\
\text { to completion of } \\
\text { design project }\end{array}$ \\
\hline
\end{tabular}

Table 11 Approaches to learning activities (based on Bailey 2002).

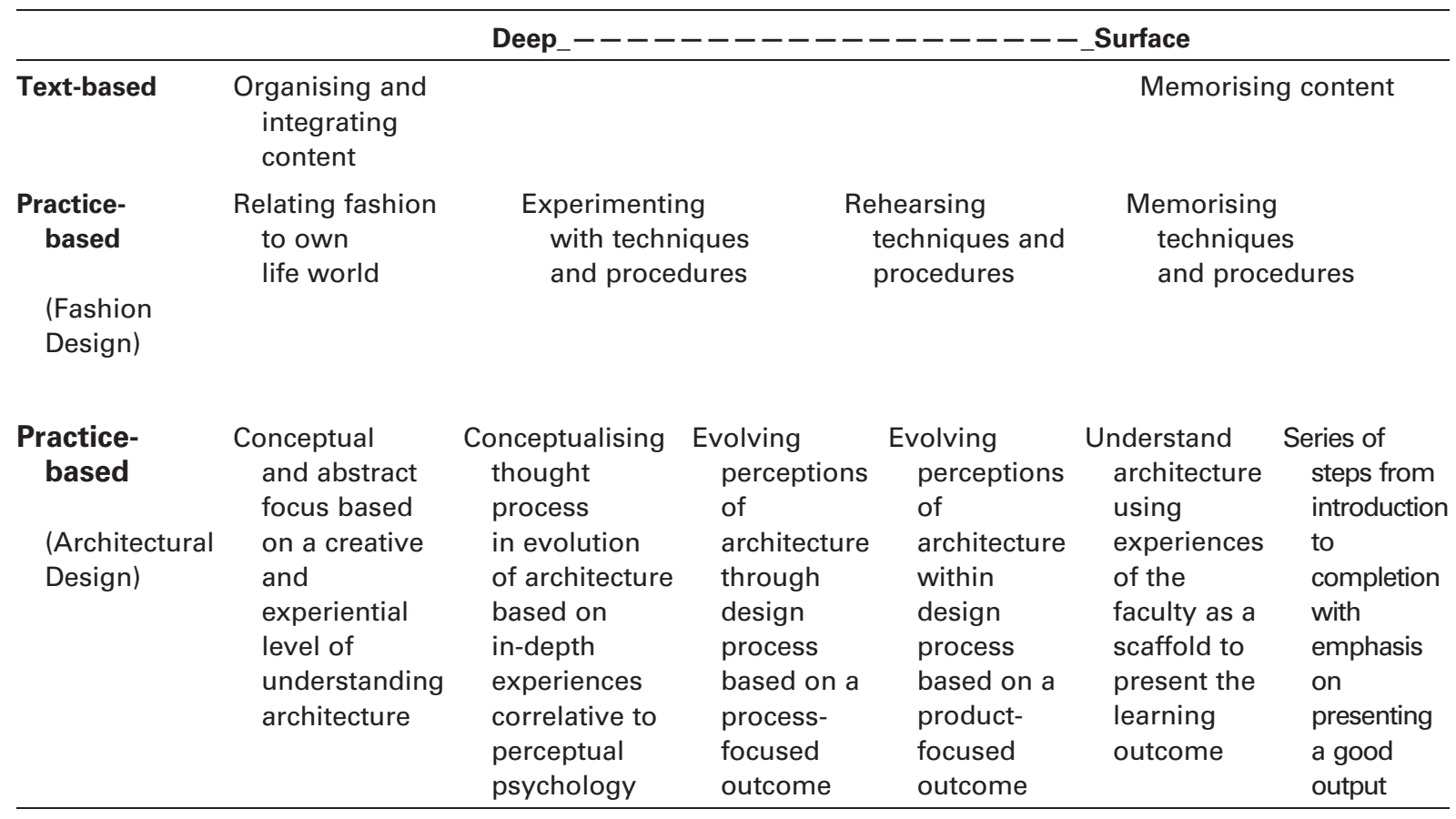

relevance in understanding how an architect actually perceives or experiences architecture (Broadbent 1988). The perceptual nature of experiencing architecture and its role in the learning approaches of the architecture student have clear relevance to the current study. The final categories of description point towards inherent perceptual experiences embedded in the architectural students' minds that seem to play a role in their approaches to learning the coursework of architectural design in the first year; but, more importantly, seem to be playing a decisive role in the fourth year of the architecture programme.

Schon's (1983) assessment of professional practice oscillating between "technical rationality ... [and] reflection-in-action" is clearly seen as the distinctive difference within the learning approaches adopted by the first year architecture students, who seem to agree with the faculty or studio coordinators and see them as scaffolds or a medium of direction in undertaking the architectural design project (Schon 1996). However, there seems to be a distinct variation amongst the fourth year architecture students, who seem to be reflecting 
upon their own experiences and perceptions of architecture rather than looking to the faculty as the medium of direction in undertaking the architectural design project.

\section{Learning Approaches in Architectural Education: The Way Forward}

The findings of this study clearly reflect the need for a further review of literature with reference to both phenomenography as a research approach and connecting the same to architectural education. This needs to be further refined with reference to the categories of approaches; this would, in turn, help in streamlining the focus and intentions of the current study's findings. The next step here would be to think about why there is a change in the approaches to learning between the first year and the fourth year and what aspects of architectural education actually facilitate such a change.

There are three further questions that need to be explored. What makes these changes happen and why is there a difference? What are the enablers? What are the barriers?

The categories of description and the findings of the current study reflected in the outcome space are based on the cross-section of first and fourth year architecture student interviews. A complete cross-section from the first to the fifth year in further studies would help in comparing the current findings and incorporating the same into the learning approaches within the entire spectrum of five years of architectural education and experience.

This study was geographically limited to architectural institutions from a specific region and the next step would be to look at the learning context from an international perspective. The randomisation of the participants was based partly on the role played by the Design Faculty for the particular year and the eagerness shown by some participants to take part in semi-structured interviews. This is being considered as a part of the collated data and the future studies to be conducted using phenomenography in architectural education.

\section{Acknowledgement}

This study was made possible due to the cooperation of both the Directors of the Rizvi College of Architecture (RCA), Bandra, Mumbai, India and the Faculty of Architecture (FoA), Manipal University, Manipal, India; with reference to the required permissions and facilitating the necessary time frame (March 2012) for the said research. The 39 first and fourth year architecture students of both institutions played an important role in bringing the study to fruition, being generous in the time they provided for conducting the semi-structured interviews.

\section{References}

Ashworth, P. and Lucas, U. (2000) Achieving Empathy and Engagement: A practical approach to the design, conduct and reporting of phenomenographic research. Studies in Higher Education 25 (3), 295-308.

Bailey, S. (2002). Student Approaches to Learning in Fashion Design: a phenomenographic study. Art, Design \& Communication in Higher Education 1 (2), 81-95.

Booth, S. (1997) On Phenomenography, Learning and Teaching. Higher Education Research \& Development 16 (2), 135-158. doi:10.1080/0729436970160203.

Broadbent, G. (1988) Design in architecture : architecture and the human sciences. London: Fulton. 
Cousin, G. (2009) Researching Learning in Higher Education, An Introduction to Contemporary Methods and Approaches. Abingdon: Routledge.

Drew, L., Bailey, S. and Shreeve, A. (2001) Phenomenographic research: methodological issues arising from a study investigating student approaches to learning in fashion design. Paper presented at the Higher Education Close Up Conference 2, Lancaster University.

Entwistle, N. (1997) Introduction: Phenomenography in Higher Education. Higher Education Research \& Development 16 (2), 127-134. doi:10.1080/0729436970160202.

Isomäki, H. (2007) Different Levels of Information Systems Designers' Forms of Thought and Potential for Human-Centered Design. International Journal of Technology and Human Interaction 3 (1), 30-48. doi:10.4018/jthi.2007010103.

Kleiman, P. (2008) Towards transformation: conceptions of creativity in higher education. Innovations in Education and Teaching International 45 (3), 209-217.

Marton, F. (1992) Phenomenography and 'the art of teaching all things to all men'. Qualitative Studies in Education 5, 253-267.

Marton, F. and Säljö, R. (1976) On Qualitative Differences in Learning: I-Outcome and Process. British Journal of Educational Psychology 46 (1), 4-11.

Säljö, R. (1997) Talk as Data and Practice - a critical look at phenomenographic inquiry and the appeal to experience. Higher Education Research \& Development 16 (2), 173-190. doi:10.1080/0729436970160205.

Schon, D.A. (1996) The Reflective Practitioner, How Professionals Think in Action. Aldershot: Arena Ashgate Publishing Limited.

Svensson, L. (1997) Theoretical Foundations of Phenomenography. Higher Education Research \& Development 16 (2), 159-171. doi:10.1080/0729436970160204.

Svensson, M. and Ingerman, Å. (2010) Discerning technological systems related to everyday objects: mapping the variation in pupils' experience. International Journal of Technology and Design Education 20 (3), 255-275. doi:10.1007/s10798-009-9084-x.

Trigwell, K. (2002) Approaches to Teaching Design Subjects: a quantitative analysis. Art, Design \& Communication in Higher Education 1 (2), 69-80.

Unwin, S. (2012) Exercises in Architecture, Learning to think as an Architect (1st ed.). Abington: Routledge.

Zoltowski, C.B., Oakes, W.C. and Cardella, M.E. (2012) Students' Ways of Experiencing Human-Centered Design. Journal of Engineering Education 101 (1), 28-59.

Zumthor, P. (1998) Thinking Architecture. Baden Baden: Lars Müller. 